\title{
Kajian Penggunaan Green Infrastruktur dalam Upaya Penurunan Suhu Permukaan di Wilayah SWK Tegalega
}

\author{
Satrio Nugraha*, Hilwati Hindersah, Irland Fardani \\ Prodi Perencanaan Wilayah dan Kota, Fakultas Teknik, Universitas Islam \\ Bandung, Indonesia. \\ *nugrahasatrio05@gmail.com, hilwati@gmail.com, irland128@gmail.com
}

\begin{abstract}
Urban heat island is a phenomenon of temperature changes caused by the concentration of building density which causes the temperature in the area to be higher than in areas with a lower density concentration. SWK Tegalega is the 1st most populous area among SWK in Bandung City according to the 2011-2031 RTRW data for Bandung City with a total population density in 2020 reaching 415 people / Ha, SWK Tegalega has at least 2.87 ha of RTH from a total area of 67.75 ha with The number of buildings is 7,683 units according to DPMPTSP (Department of Investment and One Stop Integrated Service) of Bandung City, and based on Bandung City Regulation No. 10 of 2015 the designation of the SWK Tegalega area is used as the Mediapolis area (creative industry). The data used in this research include Landsat 8 OLI satellite imagery, population density data and google earth image maps. From the processing of Landsat 8 OLI, it produces several data such as LST, SAVI and NDBI, which are used by each of these data to determine the priority areas for handling high temperature locations. After that, 4 locations were determined for handling the temperature of the area, with the use of trade \& service land, corridors, less dense settlements and dense settlements. Based on the 3D location, the average high temperature of the 4 locations ranges from $30.25-32.20^{\circ} \mathrm{C}$. After applying the green infrastructure concept from the 4 locations, the average temperature reduction of each concept used is obtained, including the tree canopy concept which has an average temperature reduction of $2.60^{\circ} \mathrm{C}$, the bioswale concept of reducing the temperature from this concept is $1.30 \mathrm{OC}$, then the green roof concept has an average temperature reduction of $0.65^{\circ} \mathrm{C}$ and the green wall concept has an average temperature drop of $<0.30^{\circ} \mathrm{C}$. Based on the results of the analysis that has been carried out, the tree canopy concept is the most effective concept in reducing the temperature at the study location.
\end{abstract}

Keywords: Urban Heat Island, Green Infrastructure, Tree Canopy, Bioswale, Green Roof, Green Wall, Decreased Temperature.

\begin{abstract}
Abstrak. Urban heat island adalah fenomena perubahan suhu yang diakibatkan oleh konsentrasi kepadatan bangunan yang menyebabkan suhu diwilayah tersebut lebih tinggi dibandingkan dengan wilayah yang memiliki konsentrasi kepadatan lebih rendah. SWK Tegalega merupakan wilayah terpadat ke-1 antara SWK di Kota Bandung menurut data RTRW Kota Bandung 2011-2031 dengan total kepadatan penduduk tahun 2020 mencapai 415 jiwa/Ha, SWK Tegalega memiliki setidaknya 2,87 ha RTH dari luas total 67,75 ha dengan jumlah bangunan 7.683 unit menurut DPMPTSP (Dinas Penanaman Modal dan Pelayanan Terpadu Satu Pintu) Kota Bandung, dan berdasarkan perda Kota Bandung no.10 tahun 2015 peruntukan kawasannya SWK Tegalega dijadikan sebagai wilayah Mediapolis (industri kreatif). Data yang digunakan dalam peneltian ini antara lain citra satelit Landsat 8 OLI, data kepadatan penduduk dan peta citra google earth. Dari pengolahan Landsat 8 OLI menghasilkan beberapa data seperti LST, SAVI dan NDBI, yang digunakan masing - masing data tersebut untuk mengetahui wilayah prioritas penanganan lokasi bersuhu tinggi. Setelah itu ditentukan 4 lokasi untuk penanganan suhu wilayah, dengan penggunaan lahan perdagangan \& jasa, koridor, permukiman tidak padat dan permukiman padat. Berdasarkan 3D lokasi didapatkan suhu tinggi rata - rata ke-4 lokasi berkisar dari $30.25-32.20^{\circ} \mathrm{C}$. Setelah diterapkan konsep green infrastruktur dari ke-4 lokasi tsb, maka didapatkan rata - rata penurunan suhu dari masing - masing konsep yang digunakan, antara lain konsep tree canopy memiliki rata - rata penurunan suhu sebesar $2.60^{\circ} \mathrm{C}$, konsep bioswale penurunan suhu dari konsep ini sebesar $1.30^{\circ} \mathrm{C}$, Kemudian konsep green roof memiliki rata - rata penurunan suhu $0.65^{\circ} \mathrm{C}$ dan Untuk konsep green wall memiliki rata - rata penurunan suhu $<0.30^{\circ} \mathrm{C}$. Berdasarkan hasil analisis yang telah dilakukan konsep tree canopy menjadi konsep yang paling efektif dalam menurunkan suhu di lokasi studi.
\end{abstract}

Kata Kunci: Urban Heat Island, Green Infrastruktur, Tree Canopy, Bioswale, Green Roof, Green Wall, Penurunan Suhu. 


\section{A. Pendahuluan}

Dengan pesatnya perkembangan di setiap kota yang terdapat di indonesia, kondisi wilayah di perkotaan banyak dialihfungsikan, yang asalnya wilayah tersebut didominasi wilayah hijau (hutan, ladang dan kebun), saat ini banyak dialihfungsikan menjadi lahan terbangun. Perihal ini menyebabkan ketidakseimbangan wilayah tersebut yang nantinya akan menyebabkan kenaik suhu. Sebanyak $15 \%$ perkotaan yang terdapat di dunia, rentan terhadap fenomena meningkatnya suhu, salah satunya adalah perbedaan suhu perkotaan-perdesaan yang dikenal sebagai pulau panas perkotaan atau urban heat island (UHI). Saat ini di beberapa negara di asia tenggara seperti contohnya Malaysia, Singapore dan Thailand mulai terancam terbentuknya pulau panas. Hal ini disebabkan oleh mulai banyaknya alih fungsi lahan dan semakin tingginya pembangunan yang menyebabkan kerapatan vegetasi semakin berkurang yang menyebabkan peningkatan suhu hingga $3,78^{\circ} \mathrm{C}$.

Dalam UU no. 26 tahun 2007 tentang penataan ruang memuat bahwa paling sedikit dibutuhkan 30\% dari seluruh luas daerah untuk dijadikan ruang terbuka hijau yang terdiri atas $20 \%$ RTH publik dan 10\% RTH privat. Kawasan tersebut dapat berupa kawasan hijau pertamanan kota, kawasan hijau hutan kota, kawasan hijau rekreasi kota serta kawasan hijau kegiatan olahraga. Hal ini dibutuhkan juga sebagai upaya peningkatan mutu lingkungan hidup perkotaan serta sebagai upaya untuk memenuhi kebutuhan oksigen bagi masyarakat perkotaan.. Kepadatan penduduk di SWK Tegalega juga mengurangi jumlah ruang terbuka hijau yang berfungsi sebagai penyerap emisi karbon karena banyaknya alih fungsi lahan. Salah satu bentuk ruang terbuka hijau yang dapat dioptimalkan sebagai penyerap emisi dan sebagai indikator penurunan suhu yaitu adalah jalur hijau. Wilayah SWK Tegalega berdasarkan data masterplan RTH Kota Bandung tahun 2010, dikatakan bahwa RTH diwilayah SWK Tegalega yaitu 2,87 ha dari luas wilayah total SWK Tegalega yaitu 67,75 ha dengan jumlah bangunan di swk karees menurut data dpmptsp Kota Bandung tahun 2017 adalah berjumlah 7.638 unit.

Berdasarkan peraturan daerah Kota Bandung nomor 10 tahun 2015, SWK Tegalega telah dijadikan sebagai pusat industri kreatif (Mediapolis) Kota Bandung, sehingga diprediksi selain meningkatkan ekonomi masyarakat akan meningkatkan aktivitas masyarakat dikawasan tersebut. Implikasi dari peraturan tersebut akan berdampak pada kepadatan penduduk, peningkatan aktivitas, dan penurunan RTH akibat banyaknya alih fungsi kawasan. Kepadatan penduduk di SWK Tegalega merupakan yang tertinggi bandung dengan salah satu kelurahannya, yaitu mencapai 415 jiwa/Ha menurut data rtrw tahun 2011 - 2031, karena Kepadatan penduduk akan berdampak lurus terhadap urban heat island, karena semakin padat makan akan menaikan suhu dan menyebabkan urban heat island [4]. lokasi SWK Tegalega sebagai wilayah studi karena dapat menjadi potensi penerapan Green Infrastruktur sebagai objek rencana dalam meningkatkan RTH yang ada di SWK Tegalega.

\section{B. Metodologi Penelitian}

\section{Metode Analisis Penentuan Lokasi Prioritas}

Dalam penentuan lokasi prioritas, analisis yang digunakan adalah analisis overlay dari ke 4 Peta yang telah dibuat, antara lain yaitu Peta Kepadatan Penduduk, Peta LST, Peta SAVI dan Peta NDBI, kemudian disatukan dan akan menghasilkan peta yang dinamakan peta lokasi prioritas. Analisis prioritas ini berfungsi untuk mendapatkan lokasi dengan prioritas yang tinggi untuk dijadikan wilayah penanganan pertama dan lokasi sampel, untuk nanti di terapkan di semua lokasi diwilayah SWK Tegalega. 


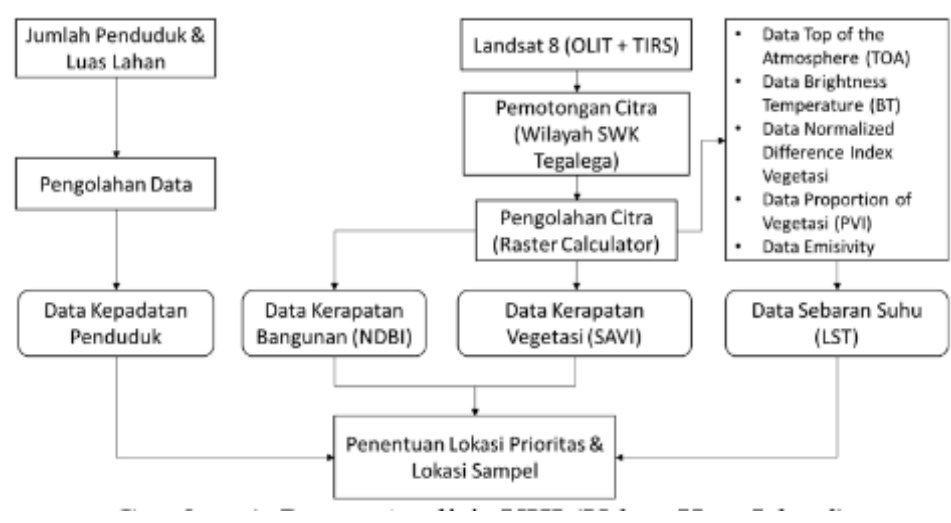

Gambar 1. Proses Penentuan Lokasi prioritas \& lokasi Sampel

Sumber : Hasil Analisis, 2021

\section{Metode Analisis Envi-Met}

Analisis ENVI-Met adalah sebuah Aplikasi atau sebuah pengembangan computational yang dimana fungsinya dapat mengsimulasikan suhu udara di area dengan dinamika iklim mikro dengan scenario tertentu. Dalam Scenario beberapa model memiliki banyak parameter keluaran (misalnya, kecepatan angin, kelembaban relatif, mean suhu radiasi, dll.), suhu udara adalah salah satu parameter yang diselidiki dalam penelitian ini. Resolusi spasial rentang ENVI-met yaitu 0,5 hingga $10 \mathrm{~m}$, dengan ukuran maksimum $50 \times 50 \times 40$ untuk versi ini, dengan resolusi maximal yaitu $2 \mathrm{~m}$ untuk ketelian citra. Adapun beberapa Parameter dalam aplikasi Envi-met ini yang dapat dilihat pada sebagai berikut.

Tabel 1. Parameter Model Calibrasi Envi-Met

\begin{tabular}{|c|l|c|}
\hline No & \multicolumn{1}{|c|}{ Parameter } & Initial Value \\
\hline 1 & Wins Speed (m/s) & $1.7-2.5$ \\
\hline 2 & Wind Direction & 315 (NNW) \\
\hline 3 & Roughness Length & 0,01 \\
\hline 4 & Initial Temperature of atmosphere $\left({ }^{\circ} \mathrm{C}\right)$ & 26 \\
\hline 5 & Spesific Humidity at model top $(2500 \mathrm{~m}, \mathrm{~g} / \mathrm{kg})$ & 60 \\
\hline 6 & Relative Humidity & No \\
\hline 7 & Forcing & Open \\
\hline 8 & Lateral Boundary Conditions (LBC) for temperature, humidity & Forced \\
\hline 9 & LBC for Turbulence & \\
\hline
\end{tabular}

Sumber: Envi-met.info

Dalam Analisis Envi - Met proses yang dilakukan adalah membuat 3D lokasi eksisting kemudian dianalisis untuk mendapatkan suhu awal. Dalam penentuan suhu awal atau cara kerja Envi-Met sendiri bahwa arah angina yang melalui bangunan akan mempengaruhi suhu bangunan atau permukaan, karena angina membawa udara panas dari pantulan cahaya matahari [5]. Kemudian setelah itu dibuat ulang 3D lokasi dengan penggunaan green infrastruktur, mendapatkan suhu akhir. Setelah itu akan mendapatkan penurunan suhu dari masing - masing konsep yang digunakan. 


\section{Hasil dan Pembahasan}

\section{Penentuan Lokasi Prioritas}

Proses penentuan lokasi ini, dimaksud untuk mendapatkan lokasi sebagai sampel untuk nantinya di terapkan di seluruh wilayah SWK Tegalega dengan mengambil lokasi tingkat "prioritas sangat tinggi" yang didapatkan berdasarkan dari hasil overlay peta yang terdiri dari peta kepadatan penduduk, kerapatan bangunan (NDBI), kerapatan vegetasi(SAVI) dan LST (Land Surface Temperatur) / Sebaran Suhu.

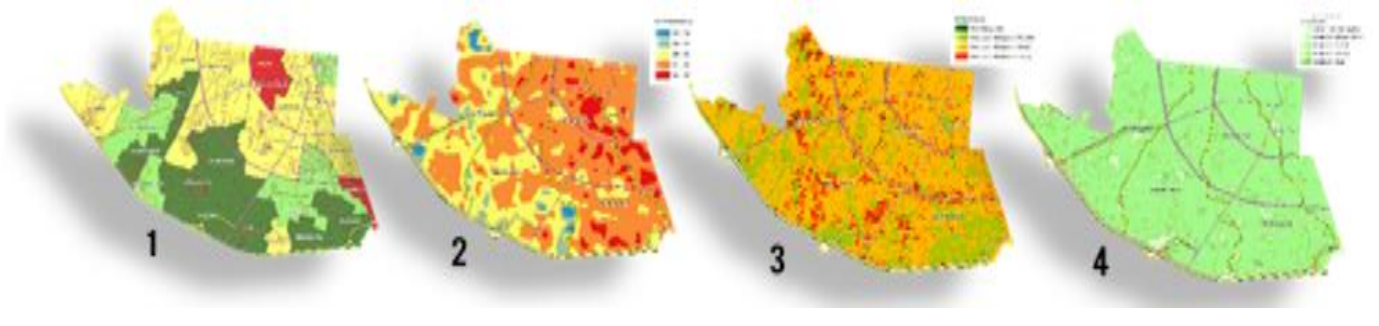

Gambar 2. Peta Kepadatan Penduduk (1), Peta LST (2), Peta NDBI (3) \& Peta SAVI (4)

Setelah mendapatkan ke-4 analisis peta, maka selanjutnya melakukan overlay dari ke-4 peta tersebut untuk mendapatkan lokasi prioritas "Sangat Tinggi". Didapatkan 6 titik lokasi prioritas "Sangat Tingi" diwilayah SWK Tegalega, kemudian ke-6 titik lokasi tersebut di validasi dengan kondisi eksisting nya untuk melihat penggunaan lahan tersebut dan apakah memiliki kesamaan antara setiap titik. Maka didapatkan 6 lokasi dengan validasi lokasi sebagai berikut.

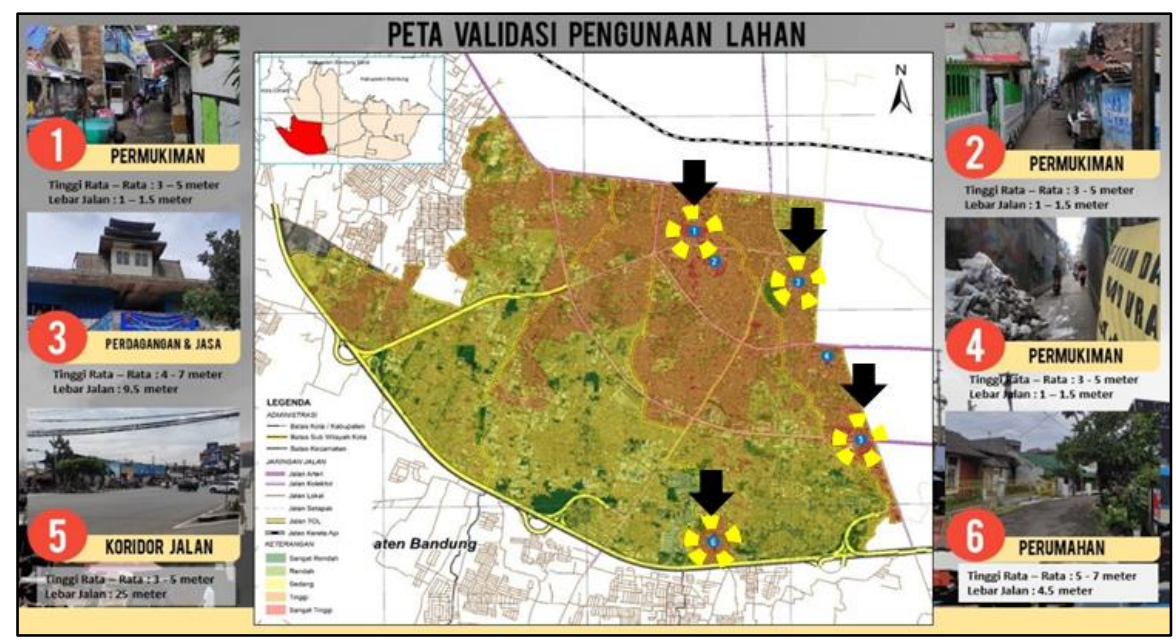

Gambar 3. Peta Validasi Penggunaan Lahan

Hasil dari peta validasi penggunaan lahan yaitu didapatkannya 4 titik lokasi dari 6 lokasi sebelumnya, yang dipilih berdasarkan jenis penggunaan lahan, karena ada 3 penggunaan lahan yang sama "Permukiman" maka hanya dipilih salah satu saja untuk mewakili penggunaan lahan permukiman.

\section{Analisis Envi-Met}

1. Penentuan Suhu Awal

Dalam penentuan suhu awal, proses yang dilakukan adalah dengan membuat 3D sederhana wilayah sampel sesuai kondisi eksisting wilayah dengan menggunakan aplikasi ENVI-Met. Kemudian setelah mendapatkan 3D sederhana lokasi eksisting, maka dilakukan rendering pada aplikasi untuk mendapatkan suhu awal. Masing - masing lokasi akan terdiri dari beberapa blad sesuai dengan luasan ke-4 lokasi, dikarenakan keterbatasan luasan pada aplikasi ENVI-Met yang berukuran 50x50x40 pixel / 100x100 ${ }^{2}$, untuk lebih jelas hasilnya dapat dilihat sebagai berikut. 
- Perdagangan Jasa

Lokasi A (Perdagangan \& Jasa) memiliki luas 400 x 400 m2 yang terbagi menjadi 4 blad, dengan ukuran per-blad nya itu $100 \times 100 \mathrm{~m} 2$ telah dilakukan analisis penentuan suhu awal lokasi dari 3D lokasi yang telah dibuat, dan didapatkan suhu wilayah yang dapat dilihat sebagai berikut.

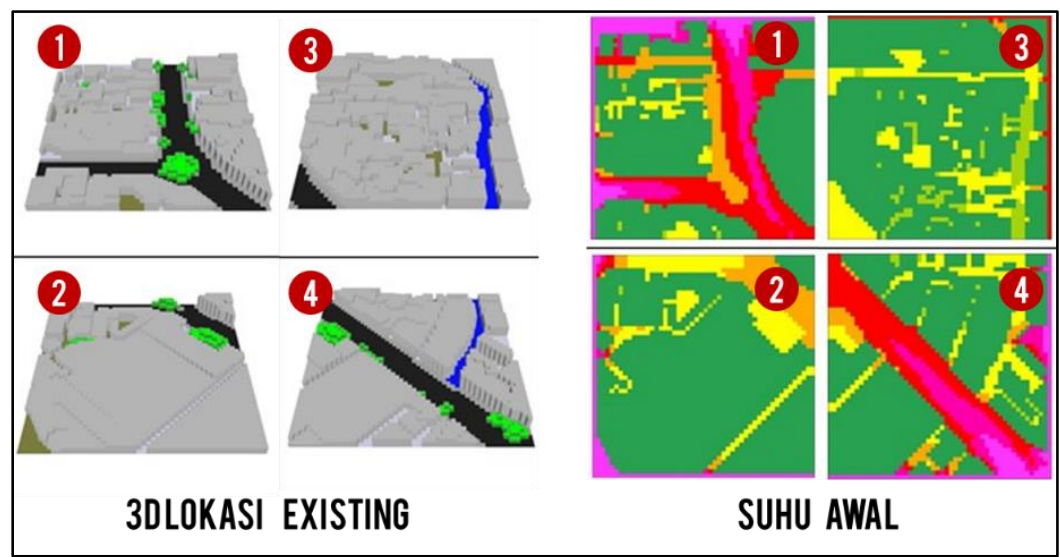

Gambar 4. Suhu Perdagangan \& Jasa

- Koridor

Lokasi B (Koridor) memiliki luas $300 \times 100 \mathrm{~m} 2$ yang terbagi menjadi 3 blad, dengan ukuran per-blad nya itu $100 \times 100 \mathrm{~m} 2$ telah dilakukan analisis penentuan suhu awal lokasi dari 3D lokasi yang telah dibuat, Untuk lebih jelasnya dapat dilihat sebagai berikut.

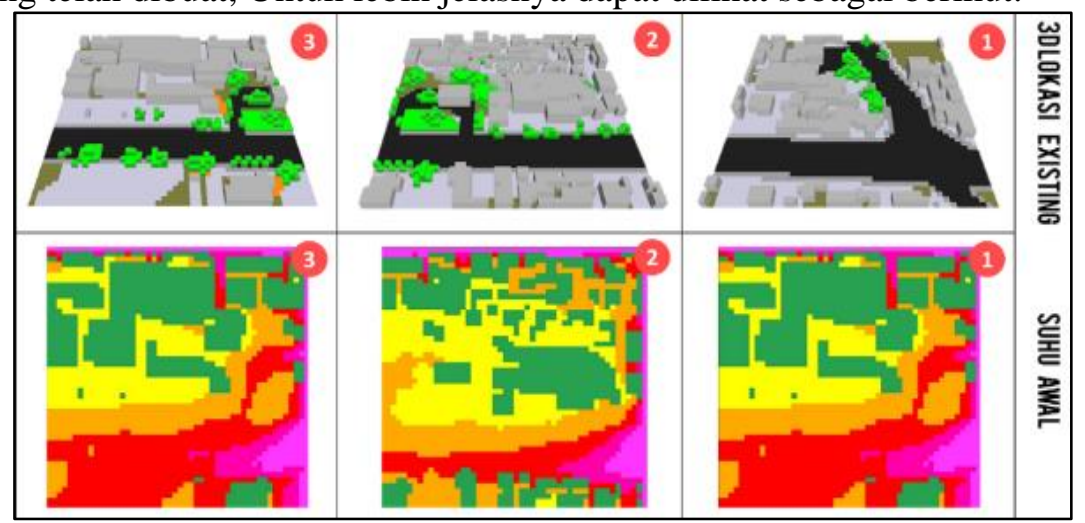

Gambar 5. Suhu Koridor 
- Permukiman Tidak Padat

Lokasi C (Permukiman tidak padat) memiliki luas 100 x $200 \mathrm{~m}^{2}$ yang terbagi menjadi 2 blad, dengan ukuran per-blad nya itu $100 \times 100 \mathrm{~m}^{2}$ telah dilakukan analisis penentuan suhu awal lokasi dari 3D lokasi yang telah dibuat, Untuk lebih jelasnya dapat dilihat sebagai berikut.

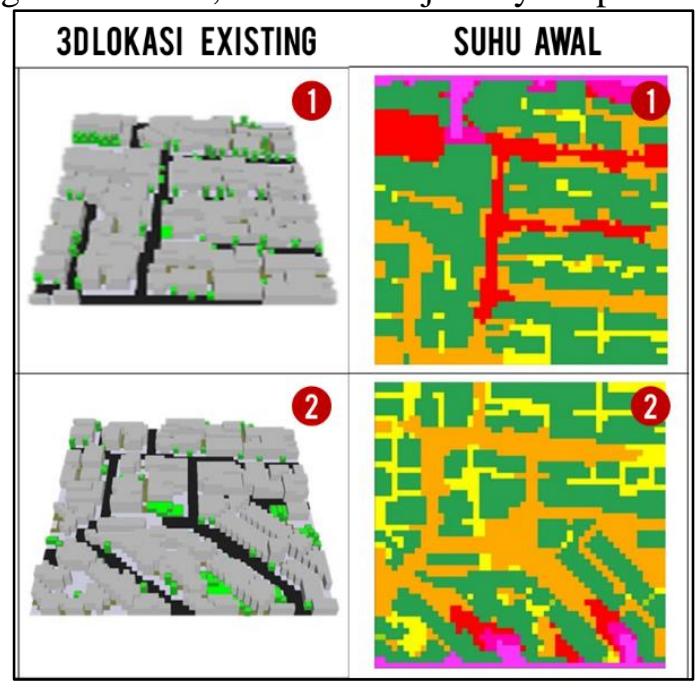

Gambar 6. Suhu Permukiman Tidak Padat

- Permukiman Padat

Lokasi D (Permukiman padat) memiliki luas $100 \times 300 \mathrm{~m}^{2}$ yang terbagi menjadi $3 \mathrm{blad}$, dengan ukuran per-blad nya itu $100 \times 100 \mathrm{~m}^{2}$ telah dilakukan analisis penentuan suhu awal lokasi dari 3D lokasi yang telah dibuat, Untuk lebih jelasnya dapat dilihat sebagai berikut.

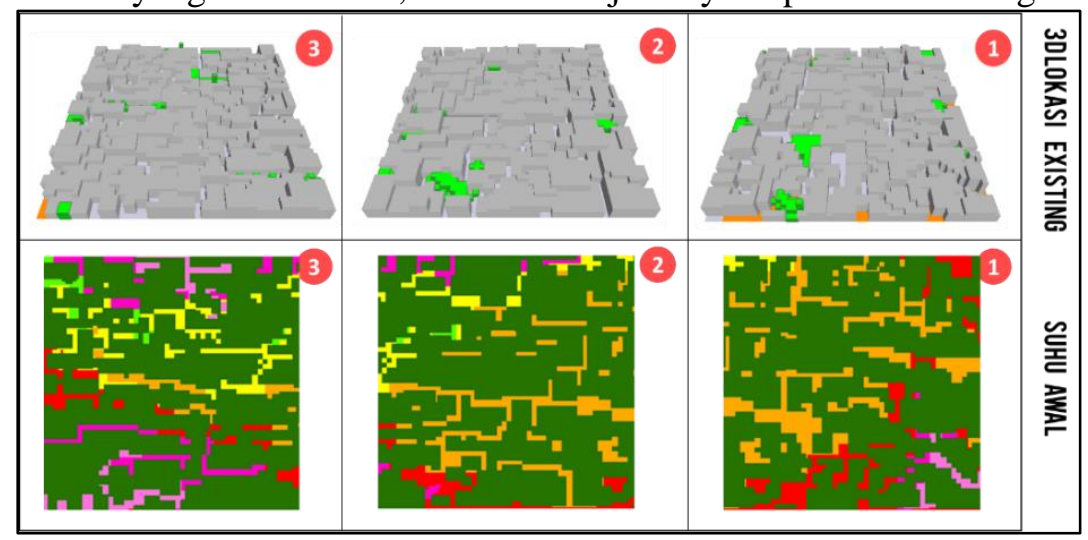

Gambar 7. Suhu Permukiman Padat

\section{Simulasi Penerapan Konsep Green Infrastruktur}

Penerapan konsep green infrastruktur yang dilakukan dalam studi kasus yang dikaji yaitu sebagai upaya penurunan suhu wilayah. Dalam upaya penurunan suhu wilayah ini penulis menggunakan konsep green infrastruktur dikarenakan infrastruktur ini ramah lingkungan, tidak menggangu siklus alami lingkungan dan juga lebih suistainable [3]. Adapun beberapa sumber lainnya yang dapat digunakan sebagai dasar untuk pemilihan konsep yang digunakan, antara lainnya dapat dilihat pada tabel berikut. 
Tabel 2. Konsep - Konsep Green Infrastruktur

\begin{tabular}{|c|l|c|c|c|c|c|c|}
\hline No & \multicolumn{1}{|c|}{ Green Infrastruktur } & $\begin{array}{c}\text { Dirtjen } \\
\text { Cipta } \\
\text { Karya } \\
\text { PUPR, } \\
2018 \text { [3] }\end{array}$ & $\begin{array}{c}\text { Briony A. } \\
\text { Norton, } \\
\text { 2015 [2[ }\end{array}$ & $\begin{array}{c}\text { Syed } \\
\text { Othman } \\
\text { Thani, } \\
\text { 2017[7] }\end{array}$ & $\begin{array}{c}\text { Teresa } \\
\text { Zolch, } \\
\text { 2016[9] }\end{array}$ & $\begin{array}{c}\text { R.U. } \\
\text { Galago } \\
\text { da, } \\
\text { 2018[6] }\end{array}$ & $\begin{array}{c}\text { Yafei } \\
\text { Wang, } \\
\text { 2020[10] }\end{array}$ \\
\hline 1 & Green Roof & $\checkmark$ & $\checkmark$ & & $\checkmark$ & & $\checkmark$ \\
\hline 2 & Green Wall & $\checkmark$ & $\checkmark$ & & & $\checkmark$ & $\checkmark$ \\
\hline 3 & Bioswale & $\checkmark$ & & & & & \\
\hline 4 & Tree Canopy & $\checkmark$ & & $\checkmark$ & $\checkmark$ & & $\checkmark$ \\
\hline
\end{tabular}

Sumber: Hasil Analisis, 2021

Konsep - konsep yang digunakan hampir mengarah kepada 4 konsep yang digunakan antara lain Green Roof, Green Wall, Bioswale dan Tree Canopy. Konsep ini akan diterapkan diwilayah kajian studi SWK Tegalega, dengan melihat priority locations, dengan ini maka beberapa konsep dapat digunakan. Maka didapatkan 4 konsep yang dapat diterapkan untuk menurunkan suhu permukaan diwilayah studi, antara lain Green Roof, Green Wall, Bioswale dan Tree Canopy.

\section{Penentuan Suhu Akhir}

Dalam analisis penentuan suhu akhir ini yaitu melakukan rendering untuk mendapatkan suhu setelah melakukan simulasi penerapan green infrastruktur. Setelah didapatkan suhu akhir, maka akan dibandingkan perubahan suhu sebelum dan sesudah dengan mengambil beberapa titik, untuk melihat parubahan suhu dari masing - masing simulasi konsep yang digunakan. Untuk lebih jelas sebaran suhu setelah penggunaan konsep green infrastruktur dapat dilihat sebagai berikut.

- Perdagangan \& Jasa

Pada lokasi A beberapa konsep green infrastruktur yang digunakan adalah green roof dan tree canopy. Kemudian didapatkan suhu tertinggi di lokasi A yaitu $30.90-31.5^{\circ} \mathrm{C}$ dengan luasan 0.001 Ha. Kemudian suhu terendah dilokasi A yaitu $<20.50^{\circ} \mathrm{C}$ dengan luasan $2.580 \mathrm{Ha}$. Untuk lebih jelas sebaran suhu di wilayah A dari masing - masing blad, dapat dilihat sebagai berikut.

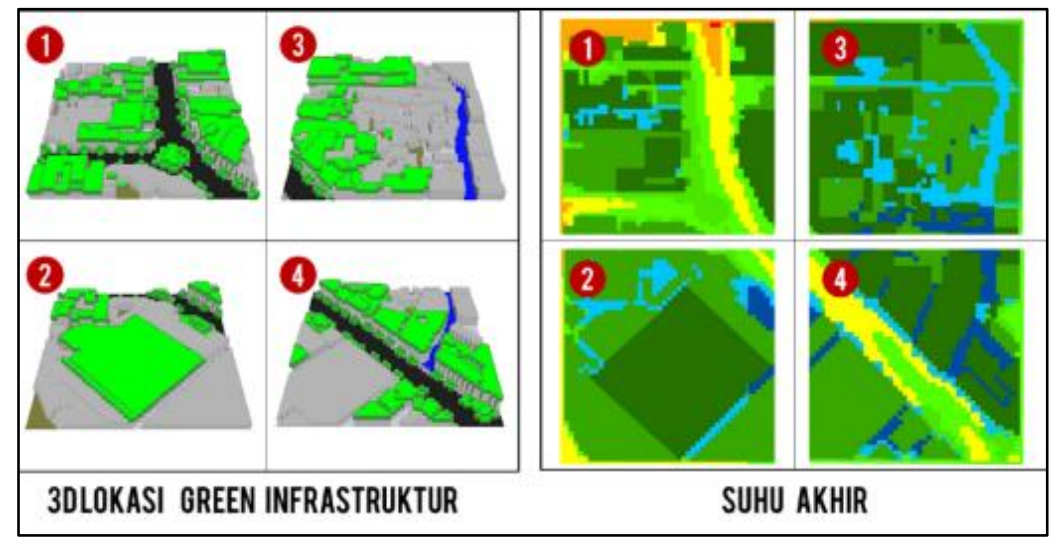

Gambar 8. Suhu Akhir Perdagangan \& Jasa 
- Koridor

Pada lokasi B beberapa konsep green infrastruktur yang digunakan adalah Green roof, Tree canopy dan Bioswale. Kemudian didapatkan suhu tertinggi di lokasi B yaitu $30.25-$ $30.90^{\circ} \mathrm{C}$ dengan luasan $0.107 \mathrm{Ha}$. Kemudian suhu terendah dilokasi B yaitu $<20.50^{\circ} \mathrm{C}$ dengan luasan 1.477 Ha. Untuk lebih jelas sebaran suhu di wilayah B dari masing - masing blad, dapat dilihat sebagai berikut.

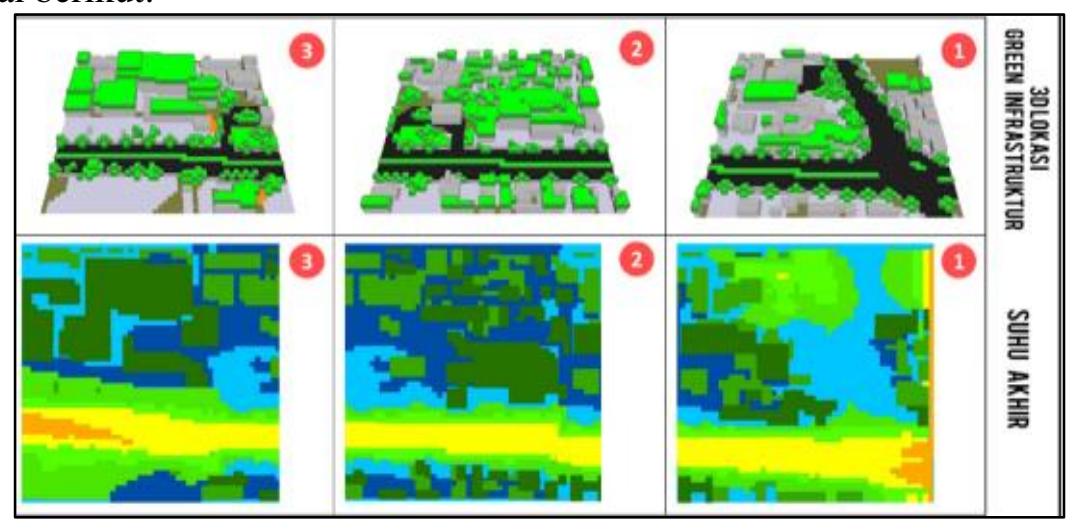

\section{Gambar 9. Suhu Akhir Koridor}

- Permukiman Tidak Padat

Pada lokasi C beberapa konsep green infrastruktur yang digunakan adalah Green roof, Tree canopy dan Bioswale. Kemudian didapatkan suhu tertinggi di lokasi $\mathrm{C}$ yaitu $>32.20^{\circ} \mathrm{C}$ dengan luasan $0.121 \mathrm{Ha}$. Kemudian suhu terendahnya yaitu $<20.50^{\circ} \mathrm{C}$ dengan luasan $1.812 \mathrm{Ha}$. Untuk lebih jelas sebaran suhu di wilayah A dari masing - masing blad, dapat dilihat sebagai berikut.

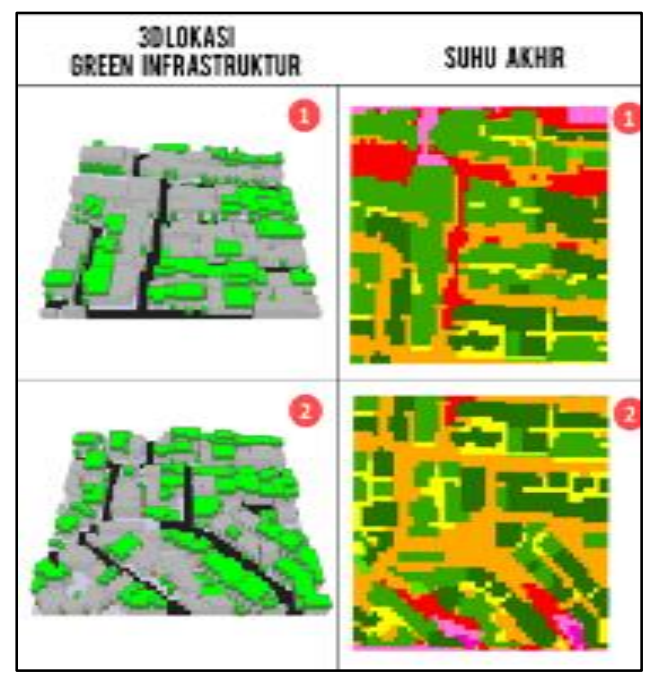

Gambar 10. Suhu Akhir Permukiman Tidak Padat

- Permukiman Padat

Pada lokasi D beberapa konsep green infrastruktur yang digunakan adalah hanya green roof, dikarenakan keterbatasan lahan dikarenakan lokasi sampel berada di wilayah padat penduduk. Kemudian setelah di analisis didapatkan suhu tertinggi di lokasi D yaitu $>32.20^{\circ} \mathrm{C}$ dengan luasan 0.079 $\mathrm{Ha}$. Kemudian suhu terendahnya yaitu $<20.50^{\circ} \mathrm{C}$ dengan luasan 2.603 Ha. Untuk lebih jelas sebaran suhu di wilayah A dari masing - masing blad, dapat dilihat sebagai berikut. 


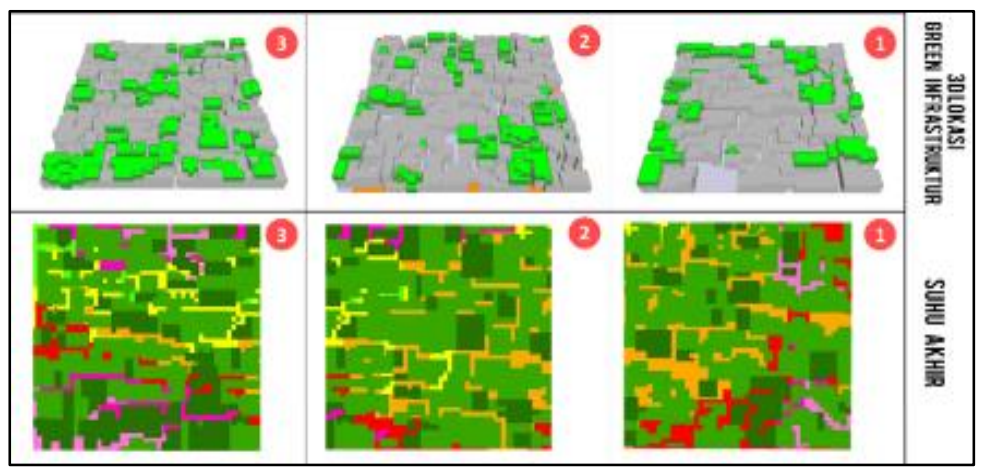

Gambar 11. Suhu Akhir Permukiman Padat

\section{Profil Perubahan Suhu}

Setelah didapatkan rata - rata perubahan suhu sebelum dan sesudah maka dapat disimpulkan konsep yang paling efektif dalam menurunkan suhu yang didapatkan dari rata - rata penurunan suhu masing - masing konsep. Untuk konsep green wall memiliki rata - rata penurunan suhu < $0.30^{\circ} \mathrm{C}$, untuk konsep green roof memiliki rata - rata penurunan suhu $0.65^{\circ} \mathrm{C}$, selanjutnya untuk bioswale memiliki rata - rata penurunan suhu $1.30^{\circ} \mathrm{C}$, dan yang terakhir untuk konsep tree canopy memiliki rata - rata penurunan suhu sebesar $2.60{ }^{\circ} \mathrm{C}$.

\section{Kesimpulan}

Berdasarkan pembahasan dalam penelitian ini, peneliti menyimpulkan beberapa hasil penelitian sebagai berikut:

Berdasarkan Hasil analisis Urban Heat Island / Suhu tertinggi di SWK Tegalega bernilai $34-36^{\circ} \mathrm{C}$ dengan luas 145.20 Ha yang mendominasi di wilayah Kecamatan Bojongloa kaler, Astana Anyar dan Bojongloa Kidul.

Berdasarkan Hasil analisis SAVI (Kerapatan Vegetasi) dan NDBI (Kerapatan Bangunan) untuk diwilayah SWK Tegalega kerapatan vegetasi di dominasi oleh tingkat "kerapatan kehijauan rendah" dan untuk kerapatan bangunan di dominasi oleh tingkat" kerapatan sedang"

Selanjutnya berdasarkan penerapkan konsep green infrastruktur dikawasan bersuhu tinggi di SWK Tegalega Didapatkan 4 lokasi sampel yang terdiri dari Perdagangan \& Jasa, Koridor, Permukiman Tidak Padat, dan Permukiman padat. Kemudian selanjutnya di terapkan konsep green infrastruktur di ke-4 lokasi, dan didapatkan penurunan suhu dari masing - masing konsep green infrastruktur yang digunakan.

1. Konsep Tree Canopy dapat menurunkan suhu sebesar $2.6^{\circ} \mathrm{C}$

2. Konsep Green roof dapat menurunkan suhu sebesar $0.65^{\circ} \mathrm{C}$

3. Konsep Green Wall dapat menurunkan suhu sekitar $<0.65^{\circ} \mathrm{C}$

4. Konsep Bioswale dapat menurunkan suhu sebesar $1.30^{\circ} \mathrm{C}$

Berdasarkan analisis perbandingan perubahan suhu didapatkan konsep yang dapat menurunkan suhu permukaan secara efektif yaitu yaitu konsep tree canopy dengan penurunan suhu yaitu $2.60^{\circ} \mathrm{C}$

\section{Ackonowledge}

Penulis mengucapkan terimakasih kepada ibu Dr. Hilwati Hindersah, Ir., MURP dan Bapak Irland Fadani, S.Si, M.T selaku dosen pembimbing yang telah memberikan bimbingan dan saran kepada penulis selama pelaksanaan dan penulis artikel ini. 


\section{Daftar Pustaka}

[1] Ardalan et al., 2016. Planning for cooler cities: A framework to prioritise green infrastructure to mitigate high temperatures in urban landscapes, University of Melbourne.

[2] Briony A. Norton, 2015. Urban heat island mitigation strategies : A state-of-the-art review on Kuala Lumpur, Singapore and Hong Kong

[3] Dirtjen Cipta Karya, 2018. Green infrastructure, subdiektorat pengembangan kawasan permukiman perkotaan.

[4] Fardani I., 2018. Dampak Perubahan Tutupan Lahan dan Kepadatan penduduk di kota bandung terhadap Urban Heat Island (UHI). Universitas Islam Bandung

[5] Hindersah H., 2017. Pembelajaran Tata Bangunan dan Lingkungan di Desa Cikole Kecamatan lembang Kabupaten Bandung Barat. Jurnal Penelitian dan Pengabdian Masyarakat. Univesitas Islam Bandung.

[6] R.U. Galagoda, 2018. The impact of urban green infrastructure as a sustainable approach towards tropical micro-climatic changes and human thermal comfort, Urban Foresty \& Urba Greening.

[7] Syed Othman Thani, 2017. Modification of urban temperature in hot-humid climate through landscape design approach, Procedia-Social and Behavioral Sciences.

[8]Teresa Zölch, 2016. Using green infrastructure for urban climate-proofing: An evaluation of heat mitigation measures at the micro-scal, Technical University of Munich (TUM).

[9] Kotharkar, R., 2018. Urban Heat Island studies in South Asia: A critical review. Urban Climate

[10] Yafei Wang, 2018. A practical approach of urban green infrastructure planning to mitigate urban overheating: A case study of Guangzhou, Sun Yat-sen University. 